\title{
$\square$
}

\section{The Rise in Personal Bankruptcies: The Eighth Federal Reserve District and Beyond}

Thomas A. Garrett

\begin{abstract}
Personal bankruptcy filings in the United States increased, per capita, nearly 350 percent between 1980 and 2005. This paper first addresses the changes in economic and institutional factors that have occurred over the past 100 years, many of which have occurred in the past 30 years, which are likely contributors to the dramatic rise in personal bankruptcy filings seen across the country. These factors include a reduction in personal savings, an increase in consumer debt, the proliferation of revolving credit, changes to bankruptcy law, and a reduced social stigma associated with filing for bankruptcy. Given the availability of bankruptcy data at various levels of aggregation, the remaining sections of the paper contain results from several different empirical analyses of bankruptcy filings using various data sets. Careful attention is paid to personal bankruptcy filings in counties located in Eighth Federal Reserve District states. (JEL D14, K35, G33)
\end{abstract}

Federal Reserve Bank of St. Louis Review, January/February 2007, 89(1), pp. 15-37.

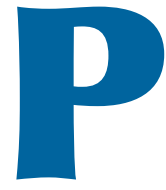

ersonal bankruptcy filings in the United States have soared over the past 30 years, from 1.2 per 1,000 persons in 1980 to nearly 5.4 per 1,000 persons in 2005, an increase of nearly 350 percent. Over this period, bankruptcies have been growing at an average annual rate of nearly 7 percent, about 1.5 times greater than the average rate of annual per capita gross domestic product (GDP) growth. Taking a longer perspective, the 2005 filing rate of 5.4 per 1,000 persons is nearly 80 times greater than the 1920 rate of 0.06 filings per 1,000 persons. $^{1}$

These statistics disguise the fact that personal bankruptcy filings are not equal across the country. For example, at the state level, Tennessee has usually had the highest rate of personal bankruptcy filings in the nation, with over 10 filings

\footnotetext{
1 Bankruptcy data are from the Administrative Office of the U.S. Courts: www.uscourts.gov/adminoff.html.

2 Tennessee ranked third in personal bankruptcies in 2005-bankruptcies per 1,000 persons were greater in Indiana and Ohio in 2005.
}

per 1,000 persons. ${ }^{2}$ Shelby County in Tennessee (Memphis area) led the nation in personal bankruptcy filings, with a rate of over 20 filings per 1,000 persons, or 2 percent of the population of Shelby County. At the other end of the spectrum, Massachusetts had a filing rate of 2.8 filings per 1,000 persons, ranking last of all states.

So what is behind this rapid increase in bankruptcy filings? The general cause of most personal bankruptcy filings is no mystery: An individual has too much debt and often also experiences an unexpected negative shock to his or her income, such as divorce, unemployment, or an uncovered medical expense. But this does not explain the increase in personal bankruptcy filings that has occurred over the past 100 years, nor does it explain the explosive growth in bankruptcy filings over the past 30 years.

The first part of the paper will discuss changes in several economic and institutional factors that are likely contributors to the dramatic rise in personal bankruptcy filings seen across the country.

Thomas A. Garrett is a research officer at the Federal Reserve Bank of St. Louis. Lesli S. Ott provided research assistance.

(C) 2007, The Federal Reserve Bank of St. Louis. Articles may be reprinted, reproduced, published, distributed, displayed, and transmitted in their entirety if copyright notice, author name(s), and full citation are included. Abstracts, synopses, and other derivative works may be made only with prior written permission of the Federal Reserve Bank of St. Louis. 
An examination of these factors may help clarify the causes of increased bankruptcy filings and may thus lead to a better understanding of the solutions to reverse this trend.

The availability of bankruptcy data at various levels of aggregation-that is, national, state, and local-affords us the opportunity to conduct temporal and cross-sectional analyses of bankruptcy filings at these different levels of aggregation. The remaining section of the paper will present and discuss the results from several different empirical analyses of bankruptcy filings using various data sets. Analysis at the national level will explore the long-run versus short-run relationship between bankruptcy filings and several key economic variables, such as the savings rate, consumer debt, and income. An analysis of state-level personal bankruptcy filings reveals that bankruptcy filing rates have been converging over time. That is, states having had higher personal bankruptcy filings are found to have had lower rates of growth in bankruptcy filings. Finally, analysis at the county level uses data for all counties in Eighth Federal Reserve District states. The county analysis explores the relationship of personal bankruptcy filings with income and the distribution of income.

\section{A BRIEF HISTORY OF BANKRUPTCY LAW IN THE UNITED STATES}

The U.S. Constitution gives Congress the authority to legislate bankruptcy. Article I, Section 8 of the Constitution reads "The Congress shall have Power To establish...uniform Laws on the subject of Bankruptcies throughout the United States.” Despite this Constitutional authority, no permanent bankruptcy law existed in the United States for the first 120 years after this country's founding. ${ }^{3}$

Three federal bankruptcy acts were passedin 1800, 1841, and 1867-but all were repealed shortly after their enactment for several reasons. First, during the late 1700s and most of the 1800s,

\footnotetext{
3 A detailed history of bankruptcy legislation in the United States can be found in Skeel (2001) and www.princeton.edu/ pefinmar/Hansen.pdf.
}

the demand for bankruptcy legislation by debtors and creditors increased during recessionary periods and diminished during boom periods. Second, strong political divides in Congress between Whigs and Federalists (Republicans), who were pro-creditor, and Democrats, who were pro-debtor, prevented the permanency of any legislation. Third, the process of filing for bankruptcy under each of the three acts was far from easy-a costly administrative structure was in place and all bankruptcy filings had to be done in one of the relatively small number of federal courts across the country.

The first long-lasting piece of bankruptcy legislation in the United States was the 1898 Bankruptcy Act. The 1898 Act was designed to aid creditors in the liquidation of an individual's assets and reorganize insolvent corporations. At the time of the 1898 Act, corporate bankruptcies accounted for the vast majority of all bankruptcy filings. Unlike the earlier acts of 1800, 1841, and 1867, the permanency of the 1898 Act was due to (i) a unified Congress and presidency (Republican) and (ii) the rapid growth and political strength of special interest groups (pro-debtor and procreditor) that culminated in the late 1800s. The rise of populism through the 1800s contributed to a strong political demand for pro-debtor bankruptcy legislation. On the other hand, the growth in business and industry over this same time period resulted in the rise of pro-business interest groups such as chambers of commerce and commercial trade groups. Competition between these growing interest groups placed great political pressures on Congress to pass long-lasting bankruptcy legislation. The 1898 Act also fostered the growth of professional bankruptcy groups that had tremendous political influence, such as the American Bar Association and Community Law League.

The Great Depression in the 1930s revealed several problems with the 1898 Bankruptcy Act. ${ }^{4}$ First, the percentage of voluntary personal bankruptcy filings grew at this time. The 1898 Act, while containing some provisions for personal bankruptcy filing, mostly addressed the issue of

\footnotetext{
${ }^{4}$ See http://eh.net/encyclopedia/article/hansen.bankruptcy.law.us.
} 
corporate bankruptcy. Second, the 1898 Act stipulated that all corporations that filed for bankruptcy be placed in corporate receivership. ${ }^{5}$ Increased business bankruptcies during the Great Depression revealed several problems, including corruption, with the structure of corporate receivership established under the 1898 Act.

The Chandler Act of 1938 was designed to remedy weaknesses of the 1898 Bankruptcy Act. Many more provisions for individual and corporate debtors were contained in the Chandler Act. For example, it allowed debtors to choose between liquidation and repayment of debt and also provided for voluntary and involuntary bankruptcy filings. As with the 1898 Act, the impetus behind the Chandler Act was the strong desire of various special interest groups, such as the American Bar Association, National Association of Credit Management, and the Commercial Law League, to change federal bankruptcy law.

The next significant piece of bankruptcy legislation was the Bankruptcy Reform Act of 1978. Between the 1930s and 1970s, corporate bankruptcy filings decreased but personal bankruptcies steadily increased. The 1978 Act (also known as the "Bankruptcy Code") replaced many earlier provisions for voluntary personal bankruptcy established by the 1898 Act. Individuals could chose between Chapter 7 filing, which provided for the liquidation of the debtor's assets, or Chapter 13, which allowed for the repayment and reorganization of a debtor's assets. ${ }^{6}$ Many of the changes to Chapter 13 made bankruptcy a more attractive option to debtors than in the past, and it is argued by some that the 1978 Act caused, at least in part, the increase in bankruptcy filings immediately following implementation of the Act. ${ }^{7}$

\footnotetext{
5 A receiver is a person or company appointed to manage a corporation during its reorganization.

${ }^{6}$ See Nelson (1999) on consumers' choice between filing Chapter 7 or Chapter 13.

7 See Shepard (1984a). Several features of the 1978 Act made filing for bankruptcy relatively more attractive than in the past: (i) federal exemption levels were increased, (ii) the requirement that creditors must approve the repayment plan under Chapter 13 was removed, (iii) Chapter 13 provided for the discharge of some debts that could not be discharged under Chapter 7, and (iv) eligibility for Chapter 13 was expanded, thus allowing almost all individuals protection from creditors under Chapter 7.
}

Additional changes to the 1978 Act were made by the Bankruptcy Reform Act of 1994, such as expediting the procedures for personal and corporate bankruptcy filings and increasing the percentage of a debtor's assets that are exempt from creditors (called the homestead exemption).

President George W. Bush signed the Bankruptcy Abuse Prevention and Consumer Protection Act of 2005 into law on April 20, 2005, with the Act taking effect on October 17, 2005. The Act was designed to reduce the number of personal bankruptcy filings that have continued to increase since the late 1970s, by increasing the cost of filings for personal bankruptcy. ${ }^{8}$ Specifically, the 2005 Act introduces two needs-based tests (based on income) for Chapter 7 filings (liquidations), requires filers to participate in credit counseling, and increases the allowable time between Chapter 7 filings to 8 years. The Act also established several requirements for lenders, such as better disclosure regarding minimum payments, interest rates (on credit cards), late payment deadlines, and introductory rates. The 2005 Act was seen by consumers as increasing the costs of filing for bankruptcy; consequently, filing rates increased dramatically (nearly six times higher than average) prior to the Act's effective date, as seen in Figure 1. Note that after October 2005, bankruptcy filings were lower than the previous two-year average. Discussions with various bankruptcy professionals reveal, however, that personal bankruptcy filings are again on the rise.

\section{THE BANKRUPTCY BOOM: CITED CULPRITS}

The primary cause of personal bankruptcy is a high level of consumer debt often coupled with an unexpected insolvency event, such as the loss of a job, a major medical expense not covered by insurance, divorce, or death of a spouse (Gropp, Scholz, and White, 1997; Buckley and Brinig,

\footnotetext{
8 The 2005 Act can be found at www.uscourts.gov/bankruptcycourts/abuseprotection.pdf. Various legal professionals in St. Louis and Memphis have commented to the author that the 2005 Act has many loopholes that result in minimal additional costs to consumers relative to earlier bankruptcy laws.
} 
Figure 1

U.S. Personal Bankruptcy Filings: Monthly, 2004 to 2005

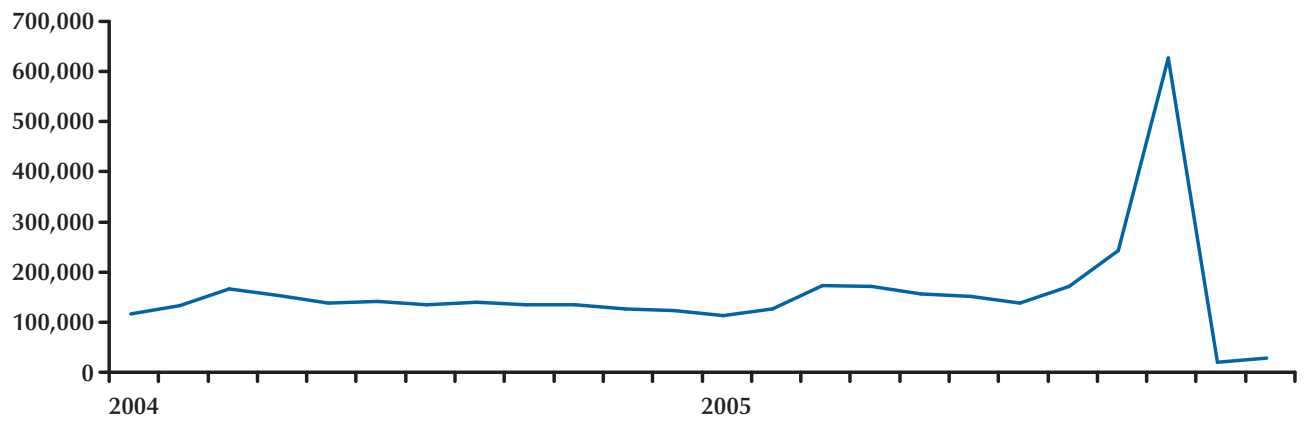

Figure 2

U.S. Personal Bankruptcies Per 1,000 Persons: 1900 to 2005

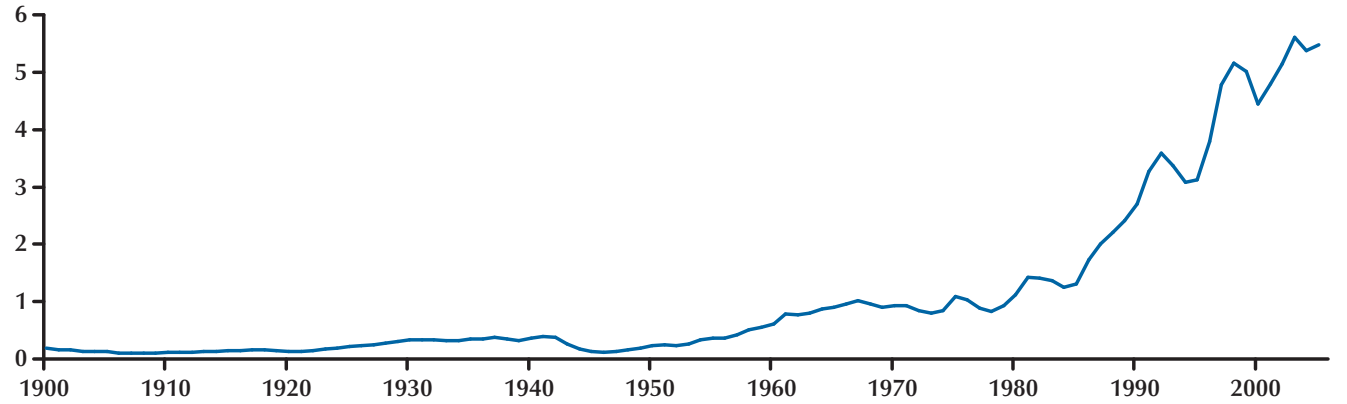

Figure 3

U.S. Consumer Saving and Debt as a Percentage of Income: Quarterly, 1980 to 2005

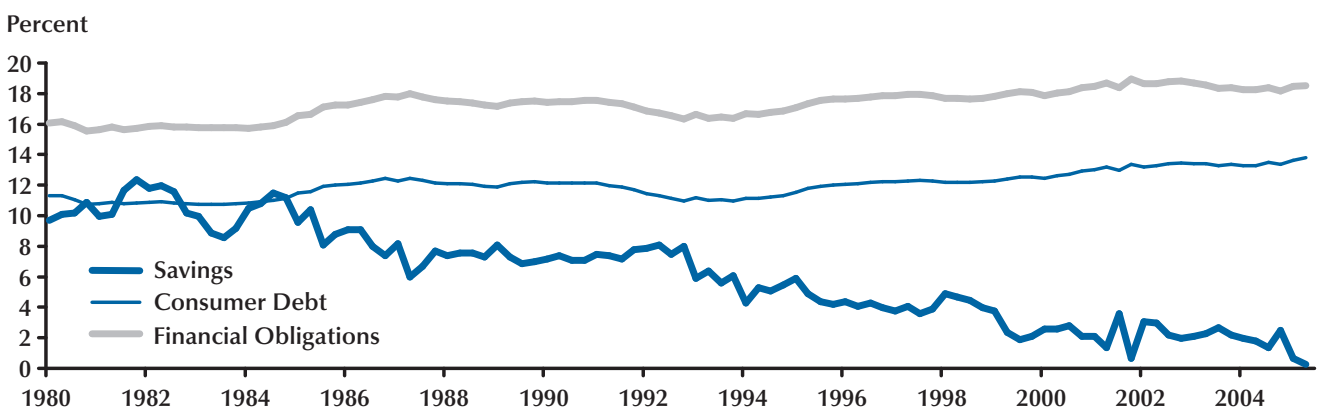


1998; and Nelson, 1999). Lower- to middle-income individuals are more likely to file for bankruptcy in response to an insolvency event, given their relatively limited access to financial counseling and fewer and less-diversified financial resources. According to consumer economists' surveys, the typical bankruptcy filer is a blue collar, high school graduate who is the head of a household in the lower-middle income class, with heavy use of credit. ${ }^{9}$ But, as mentioned earlier, this description of the average bankruptcy filer cannot by itself explain the rapid increase in personal bankruptcy filings that has occurred over the past 30 years.

It is unlikely that one event triggered the rise in bankruptcy filings. Rather, various economic and institutional changes have occurred that are likely contributors. Many of the changes discussed in this paper, such as the increased availability of credit, lower costs to filing for bankruptcy, decreased consumer savings, and increased consumer debt, do not necessarily cause bankruptcies, per se, but rather have made individuals more susceptible to negative income shocks, thus increasing the chance of bankruptcy.

\section{Economic Factors}

Personal bankruptcy filings per 1,000 persons in the United States from 1900 to 2005 are shown in Figure 2. ${ }^{10}$ Bankruptcy filings were relatively low and steady from about 1900 to 1920. Filings then increased slightly during the 1920s and 1930s. World War II saw a marked drop in filings, likely the result of increased employment in support of the war effort. After the war, the number of filings increased and continued to do so into the 1960s. Two reasons for this rise were an increase in economic activity following World War II and the rise in federal and state transfer programs such as Medicare, welfare, and disability, which (i) may have created an incentive for individuals to be less financially responsible given the expanding government safety net or (ii) is reflective of gen-

\footnotetext{
9 Shepard (1984b).

${ }^{10}$ Data prior to 1960 were obtained from Hansen and Hansen (2006); for these years, it was assumed that "miscellaneous bankruptcies" reported in Hansen and Hansen were 60 percent corporate and 40 percent personal.
}

erally poorer financial decisionmaking by lowerincome individuals. ${ }^{11}$

Corresponding with the dramatic change in bankruptcy filings since the early 1980s has been a marked decrease in consumer savings. For example, total saving as a percentage of income averaged nearly 10 percent in 1980 compared with 0.1 percent in the second quarter of 2005 (see Figure 3). ${ }^{12}$ Although rising property values have likely led to a portfolio shift from traditional savings to investing in one's home, this latter option offers much less diversity, and thus higher risk, than traditional savings.

Consumer debt has increased dramatically over the past 30 years. Consumer debt service, which includes mortgage payments and personal debt (including credit cards), as a percentage of income increased from about 11 percent of personal income in 1980 to nearly 14 percent of income in the second quarter of 2005, as seen in Figure 3. Similarly, consumer financial obligations (a broader measure than consumer debt) as a percentage of income have increased since 1980, as seen in Figure $3 .{ }^{13}$ These statistics, combined with the saving statistics, reveal that Americans have been saving less and spending more (through debt) over the past 30 years, thus making individuals more susceptible to negative income shocks and thus more likely to file for bankruptcy.

The simultaneous spread of casino gambling and rising bankruptcy rates in the 1990s has been

\footnotetext{
${ }^{11}$ Visa USA, Inc. (1996) and Edmiston (2006).

${ }^{12}$ The savings rate referred to here is the difference between disposable personal income and current consumption divided by disposable personal income. This measure of the savings rate is from the Bureau of Economic Analysis' National Income and Product Accounts (NIPA). This measure of savings is not without criticism. For example, realized capital gains are excluded, whereas taxes on realized capital gains are included. Also, pension benefits are not included in personal income but contributions to pensions are deducted from personal income. Another measure of the savings rate is based on the flow of funds (FOF) by the Federal Reserve Board of Governors. This measure computes savings as the change in net wealth divided by disposable income. The FOF measure and the NIPA measure are quite different. The FOF savings rate averaged 11.2 percent between 1954 and 2005, and the NIPA measure averaged 6.9 percent over the same time period. Although producing different estimates of the savings rate, the two measures are correlated over time.

${ }^{13}$ Financial obligations is a broader measure than consumer debt in that it considers automobile payments, rental payments, homeowners insurance, and property tax payments.
} 
noted and studied for evidence of a causal relationship. Research has provided mixed results. The U.S. Treasury Department (1999), using data from 1962 to 1998 and applying an intervention model, found no measurable effect of gambling on personal bankruptcy rates in Mississippi and New Jersey. Expanding on the study performed by the Treasury Department, de la Viña and Bernstein (2002) examined county-level bankruptcy rates for the years 1988 to 1996. The authors found no relationship between casino gambling (available within a 50-mile radius) and bankruptcy.

Thalheimer and Ali (2004) examined personal bankruptcy rates over the period 1990 to 1997 in the riverboat gambling states of Iowa, Illinois, Missouri, and Mississippi. The authors found that access to casino gambling had no significant influence on personal bankruptcies. However, the authors did estimate that personal bankruptcy rates, on average, would have been 0.4 percent lower in the absence of casino gambling.

Finally, Barron, Staten, and Wilshusen (2002) found a small localized influence of casino gambling on bankruptcy. Using county-level data for the period 1993 to 1999, the authors found that casino gambling had a positive and significant influence on personal bankruptcy. They noted that, without gambling, counties with or adjacent to casinos would have had bankruptcy rates that were 5.4 percent lower in 1998.

\section{Institutional Factors}

The rise in personal bankruptcies in the 1920s and 1930s, along with growing corruption and legal challenges regarding corporate bankruptcy filings during the Great Depression, prompted passage of the Chandler Act in 1938. The Chandler Act created a host of new options for those filing for personal bankruptcy, such as alternatives to complete liquidation (e.g., a repayment plan) and a greater ability to file voluntary petitions. The bankruptcy reforms that resulted from the Chandler Act made personal bankruptcy filing relatively more attractive and less costly than in the past.

An increased availability of consumer credit, especially in the form of credit cards, has occurred since the 1950s. ${ }^{14}$ Although proprietary charge cards were available in the early 1900s, the use of these cards was traditionally limited to a single store. Also, many of these cards did not have the feature of revolving credit. ${ }^{15}$ The first general purpose credit card (BankAmericard, now known as Visa) was introduced in 1966. In 1970, only 16 percent of families had a credit card, compared with 82 percent of families in 2000.

Table 1 shows statistics on credit card ownership and balances, broken down into family income categories for select years. ${ }^{16}$ The top portion of the table reveals that credit card ownership by all income groups has increased over time, but that wealthier families are more likely to possess a credit card. For example, in 1970, only 2 percent of the lowest income families possessed a credit card, compared with 47 percent in 2003. But, in 1970, 33 percent of the highest income families possessed a credit card, compared with 99 percent in 2003.

Not surprisingly, higher income groups tend to have higher balances. However, the important measure is balance as a percentage of incomewhich reflects the burden of credit card debt. As seen in Table 1, average credit card balances for the lowest income families are a greater percentage of family income than balances for wealthier families. In 1970, for example, credit card balances were about 5 percent of income for the lowest income families and less than 1 percent of income for the highest income families. In 2003, credit card balances were nearly 12 percent of income for the lowest income families and roughly 8.5 percent of income for the highest income families. Although wealthier families are more likely to have a credit card than lower income families, their balances are a smaller percentage of their income.

\footnotetext{
${ }^{14}$ Sienkiewicz (2001).

${ }^{15}$ Revolving credit is an agreement to lend a specific amount to a borrower and to allow that amount to be borrowed again once it has been repaid.

${ }^{16}$ Data prior to 2003 were obtained from Durkin (2000). Data for 2003 were computed using data from the Survey of Consumer Finances (2004). "Lowest" is the upper range of the first quartile (about $\$ 25,000$ in 2004), "middle" is the upper range of the third quartile (about \$66,000 in 2004), and "highest" is the lowest range of the top 5 percent (about $\$ 174,000$ in 2004). See www.census.gov/hhes/ www/income/histinc/f01ar.html for a description of the family income distribution data.
} 


\section{Table 1}

\section{Credit Card Usage and Balance by Family Income}

\begin{tabular}{|c|c|c|c|}
\hline & \multicolumn{3}{|c|}{ Income Level } \\
\hline & Lowest & Middle & Highest \\
\hline \multicolumn{4}{|c|}{ Percent of families with a credit card } \\
\hline 1970 & 2 & 14 & 33 \\
\hline 1989 & 17 & 62 & 89 \\
\hline 1998 & 28 & 72 & 95 \\
\hline 2003 & 47 & 91 & 99 \\
\hline \multicolumn{4}{|c|}{ Mean credit card balance $(\mathbf{\$})^{*}$} \\
\hline 1970 & 1,038 & 950 & 882 \\
\hline 1989 & 909 & 2,502 & 3,960 \\
\hline 1998 & 2,596 & 4,785 & 6,063 \\
\hline 2003 & 2,938 & 6,077 & 14,713 \\
\hline \multicolumn{4}{|c|}{ Mean balance as a percent of family income } \\
\hline 1970 & 4.8 & 2.0 & 0.9 \\
\hline 1989 & 3.9 & 4.2 & 2.7 \\
\hline 1998 & 10.4 & 7.4 & 3.6 \\
\hline 2003 & 11.9 & 9.1 & 8.4 \\
\hline
\end{tabular}

The late 1970s saw numerous legal changes that likely had an impact on bankruptcy filings. First, the Bankruptcy Reform Act of 1978 revamped bankruptcy practices set forth under the 1898 Act and the Chandler Act. Although the 1978 Act was passed in response to the rise in personal bankruptcies during the 1960s, many provisions in the Act made it easier for both businesses and individuals to file for bankruptcy. Academic research on the effect of the Bankruptcy Reform Act of 1978 on subsequent bankruptcy filings is mixed, however (Shepard, 1984a; and Domowitz and Eovaldi, 1993).

A second legal change in the late 1970s was a Supreme Court ruling in 1978 called the Marquette decision. ${ }^{17}$ Prior to this time, many states had usury ceilings on credit card interest

${ }^{17}$ The actual case is Marquette National Bank of Minneapolis v. First of Omaha Service Corp. See Ellis (1998) for a discussion. rates. The high inflation and interest rates of the late 1970s significantly reduced the earnings of credit card companies. As a result, credit card companies in states with relatively high interest rate ceilings attempted to solicit their credit cards to people living in states with lower interest rate ceilings-and still charge the higher interest rates.

Controversy over this practice culminated in the Supreme Court, which ruled that lenders in states with high interest rate ceilings could export those high rates to consumers residing in states with more restrictive interest rate ceilings. The result of this ruling was an expansion of credit card availability and a reduction in the average credit quality of card holders.

The third legal change in the late 1970s was the Community Reinvestment Act (CRA), which was enacted in 1977 to encourage depository institutions to help meet the credit and financing needs of the community, especially low- to moderate- 
income communities. ${ }^{18}$ Because the Act has increased credit flows to disadvantaged communities, it is possible that it also has increased the number of bankruptcy filings by lower income individuals. Research has suggested that the number of bankruptcies that result from CRA loans is, at most, 3 to 4 percent of overall bankruptcy filings. ${ }^{19}$

Although some minor legal changes to the Bankruptcy Code did occur in the 1980s, the next significant change was the Bankruptcy Reform Act of 1994. Each state has laws regarding the percentage of an individual's various assets that are exempt from creditors when that individual files for bankruptcy. These assets include insurance plans, pensions, personal property, and real estate (the homestead exemption). The federal government also sets exemption levels for these assets, and individuals may choose between using the federal exemption and their state's exemption (depending which is higher) if their state allows such a choice. ${ }^{20}$ The 1994 Act increased federal personal property exemption levels, which in essence made it less costly for individuals to file for bankruptcy because they could now keep a greater percentage of their assets. Not surprisingly, personal filings increased roughly 17 percent between 1994 and 1995 in the states affected by the higher federal exemptions.

In addition to the legal changes that have occurred over the past several decades, another potential contributor to the rise in bankruptcy filings is the decrease in the social stigma associated with filing for bankruptcy. Although such a measure is largely unquantifiable, it is not unreasonable to suspect that filing for bankruptcy becomes less undesirable as more people declare bankruptcy. It is likely that the aforementioned legal and economic changes were greater causes of the initial rise in filings rates over the past 30

\footnotetext{
18 See www.stlouisfed.org/community/about_cra.html for a discussion of the Community Reinvestment Act.

${ }^{19}$ See Gramlich (1999): www.federalreserve.gov/BoardDocs/speeches/1999/19990616.htm.

${ }^{20}$ The following states allow debtors to select the federal or state exemptions: AR, CT, HI, MA, MI, MN, NJ, NM, PA, RI, SC, TX, VT, WA, WI. See www.Bankruptcyinformation.com for detailed information on each state's bankruptcy law and exemptions.
}

years, but the public's view of personal bankruptcy arguably would have become less negative as a greater percentage of the population had filed for bankruptcy.

This section has discussed the institutional changes that are likely contributors to the rapid increase in personal bankruptcy filings; the rise in credit card usage and the relaxation of restrictions on interstate credit card provision; greater availability of credit to lower income individuals; decreased social stigma associated with bankruptcy filings; and changes to bankruptcy law that have made it less costly for individuals to file for bankruptcy.

Empirically disentangling the effect of each of the institutional changes on bankruptcy filings is quite difficult, however. As seen in Figure 2, there is a marked break in the trend level of bankruptcy filings in the late 1970s and early 1980sthe period of time that corresponds with many of the legal changes that have been hypothesized to increase the rate of bankruptcy filings. Bankruptcy filings were regressed on a time trend for two periods: 1900 to 2005 and 1978 to 2005. Not surprisingly, empirical tests revealed that the coefficient on the 1978 to 2005 time trend variable was statistically greater than the coefficient on the overall sample period. ${ }^{21}$ However, because many of these events occurred around the same period of time, it is difficult to determine the separate effects of each event on bankruptcy filings. Thus, it remains unclear whether all changes have had some effect on bankruptcy filings or the rapid rise is the result of only one or two events.

\section{THE BANKRUPTCY BOOM: NATIONAL AND REGIONAL ANALYSES 22}

\section{National Level Analysis}

The rise in personal bankruptcies over the past 30 years (Figure 2) was paralleled by an

\footnotetext{
${ }^{21}$ The coefficient (standard error) on Trend $_{1900-2005}=0.0086$ (0.0012), and the coefficient (standard error) on Trend ${ }_{1978-2005}=0.164(0.0047)$.

22 The empirical work done on the issue of personal bankruptcy is quite extensive. See, e.g., Fisher (2004, 2005), Filer and Fisher (2005), Fan and White (2003), and Nelson (1999).
} 
increase in consumer debt and a decrease in consumer savings (Figure 3). An interesting question is whether changes in the economic variables from one period to another can explain changes in bankruptcy filing rates. In other words, there appears to be a long-run relationship between bankruptcy filings and the various economic variables (Figures 2 and 3), but one cannot tell whether short-run changes in the economic variables influence short-run changes in bankruptcy filing rates.

Before considering the relationship between changes in bankruptcy and changes in these variables, however, it is useful to understand the pattern of personal bankruptcy changes quarter to quarter. Percent changes in quarterly U.S. bankruptcy filing rates from 1980 to 2005 are shown in Figure 4.

Figure 4 reveals two interesting points. First, the majority of the changes are positive rather than negative, thus showing that since 1980 there has been, overall, positive quarterly growth in bankruptcy filings. Second, quarterly filing rates increased dramatically at the start of three recessions (1980, 1990-1991, and 2001) and actually decreased in the following quarter for the latter two recessions. This suggests that the past two recessions served as housecleaning events of sorts-individuals teetering on the edge of bankruptcy immediately prior to each recession were pushed into bankruptcy from job losses, unemployment, and other setbacks resulting from the recession. After these individuals filed for bankruptcy, the number of individuals filing for bankruptcy was initially lower, as reflected by the negative growth in filing rates.

The following analysis attempts to answer the question of whether quarterly percent changes in personal bankruptcy filings are influenced by quarterly percent changes in per capita income, employment, the savings rate, health coverage, and debt as a percentage of income. Changes in these variables represent shocks to each variable. The data shown in Figure 4 are used for the analysis (1980:Q3 to 2004:Q4). The empirical model is

$$
\text { Bankruptcy }_{t}=\mathbf{X}_{t} \boldsymbol{\beta}_{k}+\mathbf{X}_{t-1} \boldsymbol{\alpha}_{k}+\mathbf{e},
$$

where Bankruptcy $y_{t}$ is the percentage change in U.S. personal bankruptcy filings per 1,000 persons in quarter $t$. The matrix $\mathbf{X}_{t}$ contains the quarterly percentage change in per capita income, payroll employment, savings as a percent of disposable income, the percent of the population covered by private/public health insurance, and consumer debt as a percentage of personal income. ${ }^{23}$ The one-period lag of each variable is included in matrix $\mathbf{X}_{t-1}$ to account for the possible lagged effect of each variable on bankruptcy filings.

Recessions may proxy for negative income shocks. Different stages of a recession may also have different effects on bankruptcy filings, as seen in Figure 4 by the large positive change and subsequent negative change occurring during recessions. Three dummy variables are included in the empirical model to capture the effects of recession stages on bankruptcies. (National Bureau of Economic Research recession dates are used.) The first variable takes a value of 1 for the first quarter of a recession and 0 otherwise. The second variable takes a value of 1 for the second quarter of a recession and 0 otherwise. Finally, the third variable takes a value of 1 for the third and all remaining quarters of a recession and 0 otherwise. Each dummy variable will reflect the average change in bankruptcy filings for the respective recession quarter relative to non-recession quarters.

Coefficient estimates from equation (1) are shown in Table 2. None of the continuous variables has a significant effect on changes in personal bankruptcy filings. The first and second quarters of a recession, however, are found to have a statistically significant effect. Specifically,

\footnotetext{
${ }^{23}$ Data sources: Personal bankruptcy filings are from the Administrative Office of the U.S. Courts, per capita income and savings as a percent of income are from the Bureau of Economic Analysis, payroll employment is from the Bureau of Labor Statistics, consumer debt as a percentage of income is from the Federal Reserve Board of Governors, and the percent of the population with public/private health insurance is from the Source Book of Health Insurance Data (for the years 1980 to 1987) and the U.S. Bureau of the Census (for the years 1988 to present). Although bankruptcy data are available through the second quarter of 2005 , these data were not used because the passage of the 2005 Bankruptcy Abuse Prevention and Consumer Protection Act was signed in April. It was thought the bankruptcy data for the first two quarters of 2005 would in part reflect action on the part of consumers to file before the Act took place.
} 
Figure 4

\section{U.S. Personal Bankruptcies: Quarterly Percent Changes, 1980 to 2005}

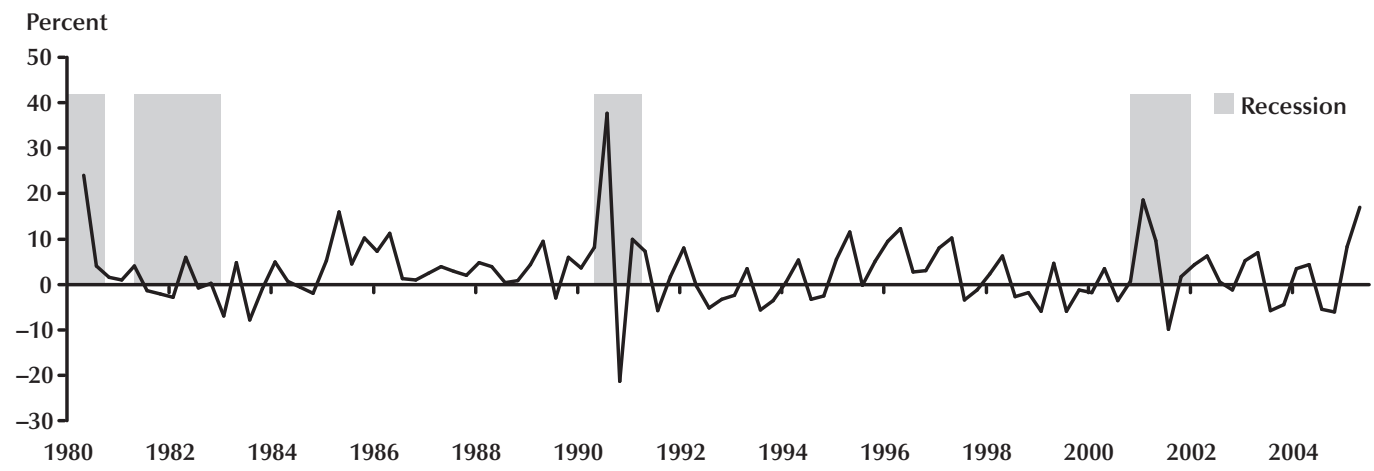

the estimates suggest that the average change in bankruptcy filings is 14.9 percentage points higher during the first quarter of a recession compared with a non-recession quarter. In the second quarter of a recession, however, bankruptcy filings are 9.2 percentage points lower than during nonrecession quarters. The first quarter and second quarter recession dummy coefficients suggest a net positive effect of recessions on bankruptcy filing rates of 5.7 percentage points $(14.9-9.2) .{ }^{24}$

To test whether the first quarter and second quarter recession dummy coefficients are statistically different in magnitude, an $F$-test was conducted on the null hypothesis that the two coefficients sum to zero. The $F$-statistic from this test is 0.764 , with a $p$-value of 0.39 . Thus, the net effect of the first two quarters of a recession on the percentage change in bankruptcy filings is not statistically different from zero. The positive increase during the first quarter of a recession is offset by a decrease of a statistically similar magnitude during the second quarter of a recession.

One study by VISA that also used national data (1980 to 1996) to empirically model bankruptcy filings found that lagged changes in employment "proved to have the single most powerful coeffi-

${ }^{24}$ The null hypothesis that the first quarter and second quarter recession coefficients are the same can be rejected at the 1 percent level $(F$-statistic $=20.09)$.

${ }^{25}$ See Visa USA, Inc. (1996). cient in explaining bankruptcy behavior." 25 The Visa study did not consider the separate effects of recession in its empirical models. To explore whether the recession variable in equation (1) is dampening the effects of employment changes, model (1) was re-estimated without the recession dummy variables. The estimated effects of employment on bankruptcy filings still remained statistically insignificant, but less so than when the recession variables were included.

The main conclusion from the national analysis presented here is that recessions (a good proxy for a negative income shock) can have significant effects (both positive and negative) on the shortterm growth in national bankruptcy filings.

Specifically, the results showed that bankruptcies increase dramatically at the start of a recession but tend to fall in the second quarter of a recession. At least for the sample period studied here, recessions serve as temporary disruptions to the trend rate of growth in personal bankruptcy filings. However, the first quarter increase and second quarter decrease are not statistically different in magnitude, so the net effect of an entire recession on bankruptcy filings is no different from that which occurs in non-recession quarters.

\section{State-Level Statistics}

Descriptive statistics on state-level bankruptcy filings and bankruptcy filing growth rates for 


\section{Table 2}

\section{Effect of Economic Variables on Bankruptcy Growth Rates}

\begin{tabular}{|c|c|c|}
\hline Variable & Coefficient & t-Statistic \\
\hline Constant & 0.020 & 1.20 \\
\hline Per capita income & -0.030 & 0.02 \\
\hline Savings as $\%$ of income & -0.002 & 0.15 \\
\hline Debt as \% of income & 0.393 & 0.25 \\
\hline Percent with health coverage & -0.205 & 0.57 \\
\hline Payroll employment & -5.027 & 1.36 \\
\hline Per capita income $(t-1)$ & -0.093 & 0.05 \\
\hline Savings as \% of income $(t-1)$ & 0.013 & 0.92 \\
\hline Debt as $\%$ of income $(t-1)$ & 0.525 & 0.36 \\
\hline Percent with health coverage $(t-1)$ & -0.327 & 0.98 \\
\hline Payroll employment $(t-1)$ & 3.847 & 1.12 \\
\hline Recession, first quarter & $0.149 * * *$ & 3.72 \\
\hline Recession, second quarter & $-0.092^{* *}$ & 2.07 \\
\hline Recession, third plus remaining quarter(s) & -0.021 & 0.60 \\
\hline$R^{2}$ & \multicolumn{2}{|c|}{0.164} \\
\hline Durbin-Watson & \multicolumn{2}{|c|}{2.21} \\
\hline Number of observations & \multicolumn{2}{|c|}{98} \\
\hline
\end{tabular}

selected years from 1980 to 2005 are shown in Table 3.

The data reveal that average state filings per 1,000 persons increased from about 1.2 in 1980, to 5.3 in 2004, and to 6.9 in 2005 . This 30 percent increase from 2004 to 2005 is, in large part, due to the increase in filings prior to the 2005 Bankruptcy Act (see Figure 1). One should keep in mind, however, that the statistics for 2005 may not represent any long-term changes from prior years if the large increase in filings prompted by the 2005 Bankruptcy Act is temporary.

The data in Table 3 reveal some interesting facts about bankruptcy filings in Eighth District states. From 1980 to 2005, bankruptcy filing rates in Eighth District states were, in most cases, in the top half to top one-third of all states. Tennessee typically has had the highest filing rate in the nation, but the state was surpassed by Indiana (rank of 1) and Ohio (rank of 2) in 2005. Arkansas experienced the greatest increase in rank, moving from 27 in 1980 to 5 in 2005, whereas Illinois had a rank of 6 in 1980 and a rank of 16 in 2005. Kentucky's ranking of 11 in 2004 remained fairly consistent over the past 25 years, including 2005. Missouri's rank has worsened over time, moving from a rank of 21 in 1980 to a rank of 11 in 2005. Mississippi, which has typically ranked in the top 10, moved from a rank of 9 in 2004 to a rank of 19 in 2005.

In 1980, Arkansas was the only Eighth District state to have had a filing rate (0.99) that was lower than the U.S. state average of 1.18. In 2004 and 2005, all Eighth District states had filing rates greater than the U.S. state average (5.34 and 6.38, respectively). In 2004, Tennessee was the only 


\section{Garrett}

Table 3

State Bankruptcy Statistics

\begin{tabular}{|c|c|c|c|c|c|c|c|c|}
\hline \multirow[b]{2}{*}{ State } & \multicolumn{4}{|c|}{ Rank } & \multicolumn{3}{|c|}{ Bankruptcies per 1,000 persons } & \multirow{2}{*}{$\begin{array}{c}\text { Average } \\
\text { annual } \\
\text { growth (\%) } \\
\text { 1980-2004 }\end{array}$} \\
\hline & 1980 & 1990 & 2004 & 2005 & 1980 & 2004 & 2005 & \\
\hline Alaska & 46 & 37 & 51 & 51 & 0.52 & 2.20 & 3.34 & 12.79 \\
\hline Alabama & 2 & 3 & 2 & 6 & 2.38 & 9.20 & 10.42 & 11.46 \\
\hline Arkansas & 27 & 22 & 4 & 5 & 0.99 & 8.69 & 10.85 & 31.17 \\
\hline Arizona & 22 & 6 & 22 & 24 & 1.18 & 5.38 & 6.68 & 14.31 \\
\hline California & 12 & 15 & 45 & 43 & 1.66 & 3.32 & 4.50 & 4.01 \\
\hline Colorado & 11 & 5 & 20 & 10 & 1.67 & 5.95 & 9.04 & 10.23 \\
\hline Connecticut & 42 & 43 & 47 & 45 & 0.59 & 3.23 & 4.31 & 17.96 \\
\hline Delaware & 36 & 45 & 35 & 39 & 0.74 & 4.09 & 4.92 & 18.10 \\
\hline Florida & 47 & 25 & 26 & 31 & 0.50 & 4.87 & 5.97 & 34.59 \\
\hline Georgia & 9 & 2 & 6 & 12 & 1.78 & 8.51 & 8.74 & 15.13 \\
\hline Hawaii & 41 & 51 & 50 & 50 & 0.59 & 2.43 & 3.46 & 12.49 \\
\hline lowa & 29 & 38 & 33 & 29 & 0.98 & 4.31 & 6.15 & 13.67 \\
\hline Idaho & 8 & 12 & 12 & 17 & 1.78 & 6.69 & 8.28 & 10.99 \\
\hline Illinois & 6 & 17 & 17 & 16 & 2.14 & 6.24 & 8.30 & 7.69 \\
\hline Indiana & 5 & 9 & 5 & 1 & 2.18 & 8.66 & 12.47 & 11.87 \\
\hline Kansas & 13 & 16 & 21 & 18 & 1.57 & 5.86 & 8.15 & 10.96 \\
\hline Kentucky & 7 & 13 & 11 & 9 & 1.95 & 6.71 & 9.55 & 9.74 \\
\hline Louisiana & 26 & 23 & 14 & 20 & 1.01 & 6.48 & 7.96 & 21.59 \\
\hline Massachusetts & 48 & 46 & 48 & 47 & 0.46 & 2.83 & 4.11 & 20.61 \\
\hline Maryland & 33 & 34 & 24 & 27 & 0.84 & 5.22 & 6.18 & 20.77 \\
\hline Maine & 38 & 49 & 44 & 40 & 0.66 & 3.32 & 4.90 & 16.08 \\
\hline Michigan & 19 & 30 & 16 & 13 & 1.37 & 6.29 & 8.73 & 14.37 \\
\hline Minnesota & 30 & 18 & 46 & 42 & 0.96 & 3.26 & 4.69 & 9.62 \\
\hline Missouri & 21 & 24 & 15 & 11 & 1.31 & 6.47 & 8.98 & 15.77 \\
\hline Mississippi & 10 & 8 & 9 & 19 & 1.75 & 7.24 & 8.04 & 12.52 \\
\hline Montana & 25 & 29 & 32 & 28 & 1.07 & 4.56 & 6.17 & 12.99 \\
\hline North Carolina & 23 & 39 & 34 & 41 & 1.15 & 4.23 & 4.88 & 10.67 \\
\hline North Dakota & 44 & 47 & 41 & 35 & 0.55 & 3.46 & 5.41 & 20.96 \\
\hline Nebraska & 16 & 27 & 25 & 23 & 1.50 & 5.03 & 6.72 & 9.41 \\
\hline New Hampshire & 40 & 33 & 42 & 46 & 0.61 & 3.46 & 4.21 & 18.51 \\
\hline New Jersey & 39 & 35 & 30 & 33 & 0.63 & 4.67 & 5.60 & 25.75 \\
\hline New Mexico & 28 & 26 & 31 & 30 & 0.98 & 4.62 & 6.01 & 14.82 \\
\hline Nevada & 3 & 4 & 10 & 7 & 2.30 & 7.14 & 9.71 & 8.41 \\
\hline New York & 24 & 40 & 37 & 34 & 1.07 & 3.94 & 5.58 & 10.66 \\
\hline Ohio & 4 & 14 & 7 & 2 & 2.22 & 7.72 & 11.65 & 9.93 \\
\hline Oklahoma & 18 & 7 & 8 & 4 & 1.38 & 7.38 & 10.85 & 17.35 \\
\hline Oregon & 14 & 11 & 13 & 15 & 1.56 & 6.57 & 8.66 & 12.88 \\
\hline Pennsylvania & 45 & 48 & 29 & 26 & 0.54 & 4.69 & 6.24 & 30.56 \\
\hline Rhode Island & 35 & 31 & 38 & 36 & 0.83 & 3.77 & 5.30 & 14.12 \\
\hline South Carolina & 51 & 44 & 39 & 49 & 0.31 & 3.64 & 3.61 & 43.15 \\
\hline South Dakota & 43 & 41 & 40 & 38 & 0.57 & 3.52 & 5.12 & 20.51 \\
\hline Tennessee & 1 & 1 & 1 & 3 & 2.60 & 10.28 & 10.96 & 11.82 \\
\hline Texas & 49 & 28 & 36 & 37 & 0.43 & 4.03 & 5.14 & 33.30 \\
\hline Utah & 20 & 10 & 3 & 14 & 1.37 & 9.03 & 8.70 & 22.43 \\
\hline Virginia & 17 & 19 & 23 & 32 & 1.48 & 5.31 & 5.90 & 10.38 \\
\hline Vermont & 50 & 50 & 49 & 48 & 0.34 & 2.60 & 4.08 & 26.42 \\
\hline Washington & 15 & 20 & 19 & 21 & 1.52 & 6.08 & 7.34 & 11.98 \\
\hline Washington, D.C. & 32 & 42 & 43 & 44 & 0.87 & 3.41 & 4.33 & 11.68 \\
\hline Wisconsin & 31 & 32 & 27 & 22 & 0.92 & 4.85 & 6.76 & 17.08 \\
\hline West Virginia & 37 & 36 & 18 & 8 & 0.74 & 6.23 & 9.62 & 29.68 \\
\hline Wyoming & 34 & 21 & 28 & 25 & 0.83 & 4.78 & 6.25 & 18.94 \\
\hline State average & & & & & 1.18 & 5.34 & 6.93 & 16.72 \\
\hline
\end{tabular}


state to have a filing rate greater than 10 per 1,000 persons (1 percent). By 2005, however, Arkansas, Indiana, and Tennessee all had filing rates greater than 10 per 1,000 persons. Over the 25-year period, bankruptcy filing rates in Missouri and Mississippi have been the closest to the U.S. state average.

The final column in Table 3 contains the average annual growth rate in bankruptcy filings from 1980 to 2004 . The year 2005 was not considered in the calculation because of the unusually high number of filings in that year, due to the 2005 Bankruptcy Act. South Carolina experienced the greatest average annual growth in bankruptcy filings, 43 percent, while California's average annual growth rate of 4 percent was the lowest in the country. Although Eighth District states have bankruptcy filing rates that are greater than the U.S. state average, average annual growth rates in six of the seven Eighth District states have been lower than the U.S. state average growth rate (16.7 percent). Arkansas experienced an average annual growth rate of 31.2 percent from 1980 to 2004, a rate nearly double that of the U.S. state average growth rate. Illinois, Kentucky, and Tennessee had the lowest bankruptcy growth rates of the Eighth District states (7.7 percent, 9.74 percent, and 11.8 percent, respectively).

A visual comparison of bankruptcy filings with average annual growth rates reveals that states with higher levels of bankruptcy filings appear to have had lower average annual bankruptcy growth rates. To explore whether this possibility has statistical validity, a simple regression model was estimated to examine the relationship between bankruptcy filings rates in 1980 and the average annual bankruptcy growth rate from 1980 to $2004 .^{26}$ The results reveal a negative and statistically significant relationship between initial filing rates (1980) and average annual bankruptcy growth rates. Bankruptcy filings are thus convergingstates that had a lower level of bankruptcy in 1980 had higher average annual growth in bankruptcy filings between 1980 and 2004. The point estimate from the regression model reveals that

\footnotetext{
26 The average annual percentage change in bankruptcy filing rates from 1980 to 2004 was regressed on bankruptcy filing rates in 1980 and a constant term. The coefficient on 1980 filings was -0.0855 and had a $t$-statistic of 5.91. The regression $R^{2}$ was 0.42 .
}

for an increase of 1 filing per 1,000 persons in 1980 , the average annual bankruptcy growth rate in a state was lower by 8.6 percentage points.

There are two possible explanations for converging bankruptcy filings. First, there are segments of each state's population that are more likely to file (e.g., lower-middle income) than other segments. Assuming the relative size of each population segment remains constant over time, there is then an upper limit on the number of people likely to file for bankruptcy. States having higher initial bankruptcy filing rates were closer to this upper limit, and thus the number of filings in these states has grown much less than in states having a larger segment of the population yet to file in the initial year.

Second, numerous studies have demonstrated the convergence of state income over time (Barro and Sala-i-Martin, 1995; Carlino and Mills, 1996; and Webber, White, and Allen, 2005). ${ }^{27}$ Because state bankruptcy rates and per capita income are negatively correlated (correlation in $2004=$ -0.453), states having a higher initial level of bankruptcy filings would have had lower income. If incomes are converging as suggested by the literature, then lower-income states would have experienced greater income growth than higherincome states, and thus the growth in bankruptcy filings in these lower-income states would have been lower.

\section{Analysis of Counties in Eighth District States}

Among Eighth District states, the counties with the 15 highest and 15 lowest bankruptcy filing rates for 2003 are shown in Table 4, along with county per capita personal income. There are 681 counties in Eighth District states, with an average

\footnotetext{
${ }^{27}$ The standard model of income convergence has been criticized for several reasons. Quah (1993) notes that implicit in the empirical specification is the idea that each economy has a steady-state growth path that follows a time trend. Durlauf (2001) points to several problems inherent in traditional convergence models, such as the potential for spillover effects and nonlinearities, a disconnect between growth theory and empirical modeling, and heterogeneous parameters. For purposes in this paper, however, differences across states in terms of heterogeneous parameters and different growth paths are likely to be significantly less than across countries because political systems and components of government revenue and spending are much more similar across states than across countries.
} 


\section{Garrett}

Table 4

County Bankruptcies in Eighth District States: 15 Highest and 15 Lowest, 2003

\begin{tabular}{|c|c|c|c|}
\hline County & State & Bankruptcies per 1,000 persons & Per capita income $(\$)$ \\
\hline \multicolumn{4}{|c|}{15 highest counties } \\
\hline Shelby & Tennessee & 20.85 & 34,087 \\
\hline Marshall & Mississippi & 16.52 & 19,224 \\
\hline Haywood & Tennessee & 15.82 & 21,792 \\
\hline Lauderdale & Tennessee & 14.58 & 18,985 \\
\hline Crittenden & Arkansas & 13.99 & 22,266 \\
\hline Hardeman & Tennessee & 13.77 & 18,884 \\
\hline Jefferson & Arkansas & 13.56 & 22,451 \\
\hline Tipton & Tennessee & 13.36 & 23,787 \\
\hline Rhea & Tennessee & 13.33 & 21,097 \\
\hline Tunica & Mississippi & 13.24 & 19,325 \\
\hline Dyer & Tennessee & 13.21 & 25,047 \\
\hline DeSoto & Mississippi & 13.15 & 28,713 \\
\hline Gallatin & Kentucky & 12.84 & 21,642 \\
\hline Marion & Indiana & 12.76 & 33,449 \\
\hline Gibson & Tennessee & 12.61 & 24,629 \\
\hline \multicolumn{4}{|c|}{15 lowest counties } \\
\hline Nodaway & Missouri & 2.76 & 20,914 \\
\hline Putnam & Missouri & 2.72 & 19,304 \\
\hline Scotland & Missouri & 2.65 & 21,113 \\
\hline Texas & Missouri & 2.58 & 17,107 \\
\hline Calhoun & Illinois & 2.54 & 22,675 \\
\hline Elliott & Kentucky & 2.47 & 14,633 \\
\hline Shannon & Missouri & 2.40 & 17,191 \\
\hline Reynolds & Missouri & 2.28 & 19,337 \\
\hline Sullivan & Missouri & 2.27 & 20,855 \\
\hline Moore & Tennessee & 2.02 & 23,166 \\
\hline Oregon & Missouri & 1.93 & 17,523 \\
\hline Chariton & Missouri & 1.46 & 24,087 \\
\hline Worth & Missouri & 1.30 & 19,559 \\
\hline Issaquena & Mississippi & 0.97 & 15,833 \\
\hline
\end{tabular}




\section{SHELBY COUNTY, TENNESSEE}

What is most interesting about Shelby County is that its demographics and economics suggest the bankruptcy rate should be much lower-per capita income in Shelby County is relatively high (about $\$ 34,000$ ), home prices are rising, unemployment is low, and consumer loan losses are not the worst in the nation (see SMR Research Corporation, "Bankruptcy Data by County," Hackettstown, NJ, available at www.smrresearch.com/cntybkrprospectus.pdf). So why is bankruptcy in Shelby County so high? This remains a mystery, but there are several possibilities. First, county-level data is an average of all sub-jurisdictions. Detailed research at the zip code or Census tract level might reveal several pockets of extremely high bankruptcy filing rates dispersed throughout the county. Thus, several small areas might be driving the Shelby County results. Second, various community and business leaders in the Memphis area have remarked that Shelby County has an unusually high number of bankruptcy attorneys, thus suggesting more filings. But, the direction of causality is unknown. That is, do more attorneys cause more filings, or are there more attorneys because filings are higher? Third, it is possible that, for whatever reason, the social stigma associated with bankruptcy filings in Shelby County has always been low.

filing rate of 7 per 1,000 persons. The majority of the counties with the highest bankruptcy filing rates in Eighth District states are located in Tennessee (eight counties). Two counties are in Arkansas, three in Mississippi, and one each in Kentucky and Indiana. Missouri and Illinois had no counties with bankruptcy filing rates in the top 15. The average filing rate in the top 15 counties was 14.2 per 1,000 persons. In Eighth District states, 10 of the 15 lowest-ranked counties are located in Missouri. The filing rate in each of the lowest 15 counties is about one-seventh that of the top 15 counties, with the lowest 15 counties having an average filing rate of 2.0 per 1,000 persons.

Table 5 presents 2003 data on county bankruptcy filings for each of the Eighth District states along with county per capita income. County rankings within each Eighth District state as well as for all counties in Eighth District states are also shown. The data in Table 5 reveal large differences in county bankruptcy filing rates within states as well as across states. In most cases, the five highest bankruptcy counties in each state had filing rates roughly three to four times that of the lowest bankruptcy counties in the state. Although filing rates in the bottom five counties of each state are similar, there is quite a large difference in the filing rates of the top five counties in each state. For example, St. Louis City (an independent jurisdiction) in Missouri had the highest bankruptcy filing rate in the state $(9.54$ per 1,000$)$, but this rate was the lowest of all top counties in other states. Also, Shelby County had the highest filing rate (nearly 21 per 1,000 persons) in Tennessee; but the county with the highest filing rate in Illinois is Knox County, with a rate of 10.5 per 1,000 persons, or nearly half that of the Shelby County rate. (See boxed insert.).

The data in Table 4 reveal that county per capita income is higher for the 15 highest bankruptcy counties in Eighth District states than for the lowest 15 bankruptcy counties. Average county per capita income for the top 15 counties is $\$ 23,692$, and average county per capita income for the bottom 15 counties is $\$ 19,521 .^{28}$ Notice also that Issaquena County in Mississippi had the lowest per capita income in the sample, but it also had the lowest bankruptcy filing rate: less than 1 per 1,000 persons. This visual positive relationship between per capita income and bankruptcy filings lends support to the findings of past research on bankruptcy filings that the

\footnotetext{
${ }^{28}$ These averages are statistically different $(t$-statistic $=3.25)$.
} 
Table 5

County Bankruptcy Statistics in Eighth District States, 2003

\begin{tabular}{|c|c|c|c|c|}
\hline County & State rank & Eighth District rank & $\begin{array}{c}\text { Bankruptcies } \\
\text { per } 1,000 \text { persons }\end{array}$ & Per capita income $(\mathbf{\$})$ \\
\hline \multicolumn{5}{|l|}{ Arkansas } \\
\hline \multicolumn{5}{|c|}{ Highest 5 counties } \\
\hline Crittenden & 1 & 5 & 13.99 & 22,266 \\
\hline Jefferson & 2 & 7 & 13.56 & 22,451 \\
\hline Arkansas & 3 & 16 & 12.51 & 26,489 \\
\hline Pulaski & 4 & 18 & 12.17 & 33,620 \\
\hline Mississippi & 5 & 21 & 12.04 & 21,738 \\
\hline \multicolumn{5}{|c|}{ Lowest 5 counties } \\
\hline Marion & 71 & 599 & 4.50 & 18,579 \\
\hline Searcy & 72 & 613 & 4.26 & 16,793 \\
\hline Fulton & 73 & 621 & 4.12 & 18,485 \\
\hline Newton & 74 & 662 & 3.02 & 16,765 \\
\hline Sevier & 75 & 663 & 3.02 & 19,926 \\
\hline \multicolumn{5}{|l|}{ Illinois } \\
\hline \multicolumn{5}{|c|}{ Highest 5 counties } \\
\hline Knox & 1 & 47 & 10.53 & 24,382 \\
\hline Vermilion & 2 & 52 & 10.45 & 23,283 \\
\hline Winnebago & 3 & 53 & 10.45 & 27,051 \\
\hline Franklin & 4 & 59 & 10.35 & 21,599 \\
\hline Marion & 5 & 85 & 9.64 & 23,920 \\
\hline \multicolumn{5}{|c|}{ Lowest 5 counties } \\
\hline DuPage & 98 & 641 & 3.64 & 44,739 \\
\hline Woodford & 99 & 647 & 3.49 & 28,585 \\
\hline Pope & 100 & 648 & 3.47 & 19,325 \\
\hline Jo Daviess & 101 & 667 & 2.84 & 30,401 \\
\hline Calhoun & 102 & 672 & 2.54 & 22,675 \\
\hline \multicolumn{5}{|l|}{ Indiana } \\
\hline \multicolumn{5}{|c|}{ Highest 5 counties } \\
\hline Marion & 1 & 14 & 12.76 & 33,449 \\
\hline Jennings & 2 & 30 & 11.33 & 22,910 \\
\hline Scott & 3 & 31 & 11.24 & 22,145 \\
\hline Madison & 4 & 33 & 11.16 & 27,207 \\
\hline Jackson & 5 & 37 & 11.01 & 25,476 \\
\hline \multicolumn{5}{|c|}{ Lowest 5 counties } \\
\hline Monroe & 88 & 558 & 5.04 & 25,162 \\
\hline Lagrange & 89 & 596 & 4.55 & 20,668 \\
\hline Dubois & 90 & 605 & 4.44 & 32,448 \\
\hline Adams & 91 & 612 & 4.27 & 24,114 \\
\hline Daviess & 92 & 619 & 4.13 & 24,088 \\
\hline \multicolumn{5}{|l|}{ Kentucky } \\
\hline \multicolumn{5}{|c|}{ Highest 5 counties } \\
\hline Gallatin & 1 & 13 & 12.84 & 21,642 \\
\hline Hopkins & 2 & 20 & 12.07 & 23,368 \\
\hline Grant & 3 & 35 & 11.10 & 21,468 \\
\hline Simpson & 4 & 41 & 10.81 & 24,146 \\
\hline Muhlenberg & 5 & 71 & 10.15 & 20,658 \\
\hline \multicolumn{5}{|c|}{ Lowest 5 counties } \\
\hline Wayne & 116 & 642 & 3.60 & 17,748 \\
\hline Clay & 117 & 653 & 3.34 & 14,874 \\
\hline Green & 118 & 655 & 3.31 & 18,257 \\
\hline Washington & 119 & 666 & 2.84 & 21,708 \\
\hline Elliott & 120 & 673 & 2.47 & 14,633 \\
\hline
\end{tabular}


Table 5, cont'd

\begin{tabular}{|c|c|c|c|c|}
\hline County & State rank & Eighth District rank & $\begin{array}{c}\text { Bankruptcies } \\
\text { per } 1,000 \text { persons }\end{array}$ & Per capita income $(\$)$ \\
\hline \multicolumn{5}{|l|}{ Missouri } \\
\hline \multicolumn{5}{|c|}{ Highest 5 counties } \\
\hline St. Louis City & 1 & 93 & 9.54 & 27,236 \\
\hline Callaway & 2 & 117 & 9.02 & 21,562 \\
\hline St. Louis & 3 & 144 & 8.61 & 43,766 \\
\hline Jackson & 4 & 221 & 7.91 & 31,966 \\
\hline Madison & 5 & 257 & 7.63 & 19,309 \\
\hline \multicolumn{5}{|c|}{ Lowest 5 counties } \\
\hline Reynolds & 111 & 675 & 2.28 & 19,337 \\
\hline Sullivan & 112 & 676 & 2.27 & 20,855 \\
\hline Oregon & 113 & 678 & 1.93 & 17,523 \\
\hline Chariton & 114 & 679 & 1.46 & 24,087 \\
\hline Worth & 115 & 680 & 1.30 & 19,559 \\
\hline \multicolumn{5}{|l|}{ Mississippi } \\
\hline \multicolumn{5}{|c|}{ Highest 5 counties } \\
\hline Marshall & 1 & 2 & 16.52 & 19,224 \\
\hline Tunica & 2 & 10 & 13.24 & 19,325 \\
\hline DeSoto & 3 & 12 & 13.15 & 28,713 \\
\hline Clay & 4 & 17 & 12.22 & 21,241 \\
\hline Tate & 5 & 23 & 11.91 & 22,818 \\
\hline \multicolumn{5}{|c|}{ Lowest 5 counties } \\
\hline Kemper & 78 & 601 & 4.48 & 17,711 \\
\hline Neshoba & 79 & 624 & 4.05 & 25,687 \\
\hline Wayne & 80 & 629 & 4.01 & 18,926 \\
\hline Smith & 81 & 633 & 3.85 & 22,783 \\
\hline Issaquena & 82 & 681 & 0.97 & 15,833 \\
\hline \multicolumn{5}{|l|}{ Tennessee } \\
\hline \multicolumn{5}{|c|}{ Highest 5 counties } \\
\hline Shelby & 1 & 1 & 20.85 & 34,087 \\
\hline Haywood & 2 & 3 & 15.82 & 21,792 \\
\hline Lauderdale & 3 & 4 & 14.58 & 18,985 \\
\hline Hardeman & 4 & 6 & 13.77 & 18,884 \\
\hline Tipton & 5 & 8 & 13.36 & 23,787 \\
\hline \multicolumn{5}{|c|}{ Lowest 5 counties } \\
\hline Hancock & 91 & 623 & 4.06 & 14,610 \\
\hline Williamson & 92 & 635 & 3.77 & 42,694 \\
\hline Clay & 93 & 645 & 3.52 & 19,576 \\
\hline Van Buren & 94 & 656 & 3.28 & 21,530 \\
\hline Moore & 95 & 677 & 2.02 & 23,166 \\
\hline
\end{tabular}

NOTE: There are a total of 681 counties in Eighth District states. All data above are for 2003. 
Figure 5

Eighth District Counties: Per Capita Income and Personal Bankruptcy Filings, 2003

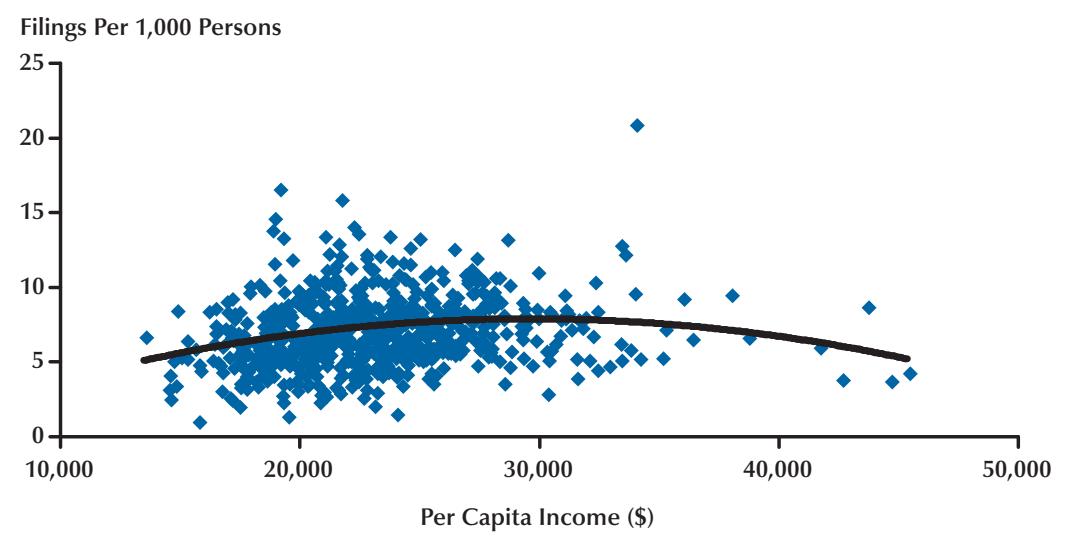

majority of bankruptcy filers are not lower income. However, this research has also established that filings are highest for individuals of lower-middle income-something that cannot be discerned from the raw data in Table 4.

\section{County Income and Bankruptcy}

A scatter plot of 2003 county per capita income and bankruptcy filing rates for all 681 counties in Eighth District states is shown in Figure $5 .^{29}$ Included in this scatter plot is a regression line obtained from regressing bankruptcies per 1,000 persons on a constant, per capita income, and the square of per capita income. The relationship between county bankruptcy filings rates and income, at least in Eighth District states, is nonlinear-bankruptcy filing rates increase with income up to a certain income level, then filing rates decrease with further increases in county per capita income. ${ }^{30}$

Figure 5 reveals that middle and lower-middle income counties have the highest filing rates, and bankruptcy filing rates for the highest income counties are very similar to the filing rates for the

29 The regression line is almost identical if Shelby County, Tennessee, is removed from the sample.

${ }^{30}$ The results are very similar when median county household income is used rather than per capita personal income. These results will be provided upon request. lowest income counties. This is likely reflective of the fact that the poorest of the poor cannot acquire credit or other assets, thus there is no chance of accumulating too much debt that filing for bankruptcy may alleviate. Wealthier individuals, on the other hand, have greater incomes and more financial diversification that shield them from negative income shocks, and their higher levels of education make it more likely they better understand the risks of acquiring debt, are less likely to do so, and are thus less likely to file for bankruptcy.

In addition to the full sample of counties, the same regression was estimated for each of the Eighth District states. These results, along with the coefficients from the full sample regression, are shown in the first two data columns of Table 6. In general, there appears to be a similar nonlinear relationship between county income and county bankruptcy filings within each Eighth District state (as seen by the positive coefficient on income and the negative coefficient on the square of income). However, not all income coefficients are statistically significant. ${ }^{31}$

\footnotetext{
${ }^{31}$ The adjusted $R^{2}$ from each regression is also relatively low. The inclusion of other (possibly) relevant variables proved difficult at the county level, given that debt and savings figures are not readily available at this level of disaggregation. In addition, many demographic variables, such as ethnicity and population density, are commonly correlated with income.
} 
Table 6

County Bankruptcy and Income

\begin{tabular}{|c|c|c|c|c|c|c|}
\hline \multirow[b]{2}{*}{ State } & \multicolumn{3}{|c|}{ Per capita income } & \multicolumn{3}{|c|}{ Percent in poverty } \\
\hline & Variable & Coefficient & $t$-Statistic & Variable & Coefficient & $t$-Statistic \\
\hline \multirow[t]{5}{*}{ Arkansas } & Constant & -11.233 & 1.31 & Constant & $10.909^{* * *}$ & 2.71 \\
\hline & Income & $0.0014^{*}$ & 1.85 & Poverty & -0.419 & 1.01 \\
\hline & Income ${ }^{2}$ & $-0.216 \mathrm{e}-7$ & 1.41 & Poverty ${ }^{2}$ & 0.0138 & 1.35 \\
\hline & Adjusted $R^{2}$ & \multicolumn{2}{|c|}{0.205} & Adjusted $R^{2}$ & \multicolumn{2}{|c|}{0.026} \\
\hline & $\mathrm{H}_{0}: \beta_{2}=\beta_{3}=0$ & \multicolumn{2}{|c|}{$10.53^{* * *}$} & $\mathrm{H}_{0}: \beta_{2}=\beta_{3}=0$ & \multicolumn{2}{|c|}{1.99} \\
\hline \multirow[t]{5}{*}{ Illinois } & Constant & -0.203 & 0.07 & Constant & $3.715^{* * *}$ & 3.32 \\
\hline & Income & $0.00052^{* * *}$ & 2.70 & Poverty & $0.378^{* *}$ & 2.12 \\
\hline & Income $^{2}$ & $-0.967 \mathrm{e}-8^{* * *}$ & 3.33 & Poverty $^{2}$ & -0.0095 & 1.44 \\
\hline & Adjusted $R^{2}$ & \multicolumn{2}{|c|}{0.051} & Adjusted $R^{2}$ & \multicolumn{2}{|c|}{0.064} \\
\hline & $\mathrm{H}_{0}: \beta_{2}=\beta_{3}=0$ & \multicolumn{2}{|c|}{$3.73^{* *}$} & $\mathrm{H}_{0}: \beta_{2}=\beta_{3}=0$ & \multicolumn{2}{|c|}{$4.45^{* *}$} \\
\hline \multirow[t]{5}{*}{ Indiana } & Constant & 0.732 & 0.14 & Constant & 2.914 & 1.29 \\
\hline & Income & 0.00051 & 1.45 & Poverty & $1.011^{* *}$ & 2.01 \\
\hline & Income $^{2}$ & $-0.897 \mathrm{e}-8$ & 1.55 & Poverty ${ }^{2}$ & $-0.0479 *$ & 1.74 \\
\hline & Adjusted $R^{2}$ & \multicolumn{2}{|c|}{-0.006} & Adjusted $R^{2}$ & \multicolumn{2}{|c|}{0.026} \\
\hline & $\mathrm{H}_{0}: \beta_{2}=\beta_{3}=0$ & \multicolumn{2}{|c|}{0.69} & $\mathrm{H}_{0}: \beta_{2}=\beta_{3}=0$ & \multicolumn{2}{|c|}{2.22} \\
\hline \multirow[t]{5}{*}{ Kentucky } & Constant & -5.283 & 1.62 & Constant & $7.256^{* * *}$ & 5.11 \\
\hline & Income & $0.00093^{* * *}$ & 3.22 & Poverty & 0.0552 & 0.34 \\
\hline & Income ${ }^{2}$ & $-0.170 \mathrm{e}-7^{* * *}$ & 2.76 & Poverty ${ }^{2}$ & -0.0051 & 1.16 \\
\hline & Adjusted $R^{2}$ & \multicolumn{2}{|c|}{0.144} & Adjusted $R^{2}$ & \multicolumn{2}{|c|}{0.147} \\
\hline & $\mathrm{H}_{0}: \beta_{2}=\beta_{3}=0$ & \multicolumn{2}{|c|}{$11.00^{* * *}$} & $\mathrm{H}_{0}: \beta_{2}=\beta_{3}=0$ & \multicolumn{2}{|c|}{$11.23^{* * *}$} \\
\hline \multirow[t]{5}{*}{ Missouri } & Constant & -1.174 & 0.57 & Constant & $8.343^{* * *}$ & 5.49 \\
\hline & Income & $0.00034^{* *}$ & 2.22 & Poverty & $-0.426^{*}$ & 1.77 \\
\hline & Income ${ }^{2}$ & $-0.318 \mathrm{e}-8$ & 1.14 & Poverty ${ }^{2}$ & 0.012 & 1.29 \\
\hline & Adjusted $R^{2}$ & \multicolumn{2}{|c|}{0.191} & Adjusted $R^{2}$ & & \\
\hline & $\mathrm{H}_{0}: \beta_{2}=\beta_{3}=0$ & 14. & $* * *$ & $\mathrm{H}_{0}: \beta_{2}=\beta_{3}=0$ & & \\
\hline Mississippi & Constant & -1.670 & 0.39 & Constant & $9.769 * *$ & 2.15 \\
\hline & Income & $0.00075^{* *}$ & 2.17 & Poverty & -0.135 & 0.31 \\
\hline & Income $^{2}$ & $-0.142 \mathrm{e}-7^{* *}$ & 2.10 & Poverty ${ }^{2}$ & 0.0014 & 0.14 \\
\hline & Adjusted $R^{2}$ & & & Adjusted $R^{2}$ & & \\
\hline & $\mathrm{H}_{0}: \beta_{2}=\beta_{3}=0$ & 1. & & $\mathrm{H}_{0}: \beta_{2}=\beta_{3}=0$ & & \\
\hline Tennessee & Constant & -4.090 & 0.88 & Constant & 1.577 & 0.49 \\
\hline & Income & $0.00089^{* *}$ & 2.37 & Poverty & $0.931^{* *}$ & 2.14 \\
\hline & Income $^{2}$ & $-0.145 \mathrm{e}-7^{*}$ & 1.91 & Poverty $^{2}$ & $-0.031^{* *}$ & 2.14 \\
\hline & Adjusted $R^{2}$ & & & Adjusted $R^{2}$ & & \\
\hline & $\mathrm{H}_{0}: \beta_{2}=\beta_{3}=0$ & & & $\mathrm{H}_{0}: \beta_{2}=\beta_{3}=0$ & & \\
\hline Eighth District & Constant & -1.813 & 1.33 & Constant & $6.056^{* * *}$ & 11.00 \\
\hline & Income & $0.00064^{* * *}$ & 6.00 & Poverty & $0.135^{*}$ & 1.86 \\
\hline & Income ${ }^{2}$ & $-0.108 \mathrm{e}-7^{* * *}$ & 5.19 & Poverty ${ }^{2}$ & $-0.0042^{*}$ & 1.93 \\
\hline & Adjusted $R^{2}$ & & & Adjusted $R^{2}$ & & \\
\hline & $\mathrm{H}_{0}: \beta_{2}=\beta_{3}=0$ & 19. & $* * *$ & $\mathrm{H}_{0}: \beta_{2}=\beta_{3}=0$ & & \\
\hline
\end{tabular}

NOTE: The dependent variable is bankruptcies per 1,000 persons. Sample sizes: $A R=75, I I=102, I N=92, K Y=120, M O=115, M S=82$, $\mathrm{TN}=95$, Eighth District $=681 . F$-statistic presented for tests of joint significance. ${ }^{*} / * * * * *$ denote significance at the 10/5/1 percent levels. Standard errors are corrected for heteroskedasticity. 
Table 7

\section{County Income and Bankruptcy Filings}

\begin{tabular}{|c|c|c|c|c|}
\hline State & $\begin{array}{l}\text { Level of per capita } \\
\text { county income } \\
\text { that maximizes } \\
\text { bankruptcy filings }(\$)\end{array}$ & $\begin{array}{c}\text { Number of } \\
\text { counties below } \\
\text { maximizing } \\
\text { income level }\end{array}$ & $\begin{array}{c}\text { Number of } \\
\text { counties above } \\
\text { maximizing } \\
\text { income level }\end{array}$ & $\begin{array}{c}\text { Average } \\
\text { county per capita } \\
\text { income, } 2003(\$) \\
\end{array}$ \\
\hline Arkansas & 31,692 & 74 & 1 & 21,452 \\
\hline Illinois & 26,901 & 74 & 28 & 25,335 \\
\hline Indiana* & 28,726 & 72 & 20 & 26,137 \\
\hline Kentucky & 27,327 & 104 & 16 & 22,040 \\
\hline Missouri & 53,572 & 115 & 0 & 22,846 \\
\hline Mississippi & 26,442 & 75 & 7 & 20,870 \\
\hline Tennessee & 30,434 & 89 & 6 & 23,330 \\
\hline Eight District & 29,698 & 631 & 50 & 23,197 \\
\hline
\end{tabular}

NOTE: The above values are estimated using the coefficient estimates from a regression of county bankruptcy filing rates on income and income squared. See Table 6 for coefficient estimates. *For Indiana, the slope coefficients (see Table 6 ) used to compute maximum income are neither individually significant nor jointly significant at conventional levels.

The empirical results shown in Table 6 can be used to determine the level of county per capita income for which bankruptcy filings are the highest. ${ }^{32}$ With this information, the number of counties in each state that are above and below this maximum value can be computed. For the full sample of Eighth District states and each individual Eighth District state, the level of county per capita income that maximizes personal bankruptcy filings and the number of counties above and below this value are shown in Table $7 .{ }^{33}$

\footnotetext{
${ }^{32}$ Using the estimates from each state and the full sample shown in Table 6, the level of per capita income that maximizes personal bankruptcy rates is found by differentiating bankruptcy filings with respect to income, setting this expression equal to zero, and solving for income. The second derivatives are negative, thus confirming a maximum.

${ }^{33}$ Several caveats are worth mentioning. First, the values in Table 7 are based solely on the estimates shown in Table 6 and not the statistical significance of these estimates. Second, although county data is much more disaggregated than state or national data, it is still relatively aggregate data. The analysis here attempts to make inferences about individual level behavior using county-level data. Similarly, county boundaries are political boundaries, not necessarily economic boundaries; that is, local economic conditions are not contained within county boundaries. Third, counties in Eighth District states are only a subsample of all U.S. counties, and counties in Eighth District states have per capita income below U.S. per capita income. For example, in 2003, U.S. per capita income was $\$ 31,484$; in Eighth District states it was $\$ 23,197$. Thus, the sample of counties used here was of relatively poorer counties compared with the U.S. average.
}

For all Eighth District states, the level of county per capita income that maximizes bankruptcy filings is relatively high, as can be seen by the fact that all bankruptcy-maximizing income values are above the average county per capita income. What this reveals is that there is generally a positive relationship between county per capita income and bankruptcy filings for all but the wealthiest counties in each state; and, for the wealthiest counties, the relationship between per capita income and bankruptcy filings is negative. It is interesting to note that this relationship holds, in general, for states having relatively significant differences in per capita income.

Per capita income provides a measure of average county income and thus does not provide any insights into the distribution of income. The previous analysis of county bankruptcy filings using per capita county income is therefore redone using the percent of the population below poverty. For each state in the Eighth District as well as the full sample of counties, county bankruptcies per 1,000 persons in 2003 is regressed on the percent of the population in poverty in 2003 and this percent squared. Conducting such an analysis provides insights into how county bankruptcy filings 
differ across counties with different percentages of their populations below the poverty level. ${ }^{34}$

The empirical results from the regression models are also shown in Table 7 . The results are statistically weaker than the results from the per capita income models, but there is some evidence of a similar relationship with bankruptcy filings. That is, bankruptcy filings generally increase with poverty, but at a decreasing rate. A rationale for this finding is the same as that for the per capita income results-namely, that the poorest individuals cannot acquire credit or other assets and thus gain little or nothing by filing for bankruptcy because no assets are held. Note, however, the estimated poverty coefficients for Missouri (statistically significant) and Arkansas (not statistically significant) suggest that, in those states, county bankruptcies decrease as the percent of the population in poverty increases, but at a decreasing rate.

The results from the full sample of counties reveal that bankruptcy filings increase with poverty at a decreasing rate, although the two poverty coefficients are not jointly significant at conventional levels. The level of poverty that maximizes filings for the full sample is 16.2 percent. Of the 681 counties in Eighth District states, 208 counties (about 31 percent) had poverty levels greater than 16.2 percent. As cautioned earlier, however, the poverty results are generally less robust across the sample of states and, thus, conclusions are less definitive than those obtained from the per capita income models.

\section{CONCLUDING COMMENTS}

The rapid rise in bankruptcy filings can be attributed to numerous economic and institutional factors. Increased consumer debt as a percentage of income, decreased savings, and widespread credit card availability and usage have all made individuals more vulnerable than in the past.

\footnotetext{
${ }^{34}$ Models were also estimated that included both income variables and both poverty variables. Some of the results were quite different from those presented in Table 6. This is likely the result of a high degree of colinearity between per capita income and the percent of the population below the poverty level (average $\rho=0.65$ ). These results will be provided upon request.
}

Consumers today face an increased probability of bankruptcy when hit with negative income shocks, such as divorce, job loss, and medical expenses. Legal changes have also contributed to the rise in bankruptcy by making it less costly (or more attractive) for individuals to file for bankruptcy. Greater access to credit by lower and middle income households that may not have adequate financial education is another cited factor. Finally, there has been a decrease in the social stigma associated with filing for bankruptcy.

The analyses presented in this article reveal some interesting insights into bankruptcy filing rates. At the national level, filing rates are 14.9 percentage points higher during the first quarter of a recession compared with non-recession quarters. However, bankruptcy filing rates are 9.2 percentage points lower in the second quarter of a recession compared with non-recession quarters. The net effect of the first quarter and second quarter of a recession are not statistically different, however, thus suggesting that a recession has no net effect on bankruptcy filing rates. Recessions appears to cause, at least as indicated in nationallevel data, a so-called housecleaning effect on bankruptcy filings. However, despite the short-run shocks to bankruptcy filings from recessions, the upward trend in bankruptcy filings has continued.

Personal bankruptcy rates are quite different across states, especially those states in the Eighth Federal Reserve District. These states, as a whole, have a filing rate that is greater than the U.S. average filing rate. An analysis of state-level bankruptcy filings revealed that states with higher levels of bankruptcy filings in 1980 experienced slower annual bankruptcy growth rates through 2004. There thus appears to be convergence in state bankruptcy filings.

An analysis of bankruptcy filing rates and income in those counties located in Eighth District states revealed a nonlinear relationship between the two variables. Bankruptcy filings were found to increase with county income, but only to a certain point. After a certain income level, it was found that bankruptcy filings decrease with income. It was shown that for most states in the Eighth District, the bulk of each state's counties had a level of per capita income that was below 
the bankruptcy-maximizing level. Thus, for most counties in Eighth District states, bankruptcy filing rates increase with county income. This nonlinear relationship between income and bankruptcy filings reflects the fact that those individuals with the lowest incomes are likely to have few assets and limited access to credit, thus making it unlikely that they could incur debt, default, and file for bankruptcy. Empirical evidence also revealed a nonlinear relationship between county bankruptcy filings and the percent of the county population in poverty, but this relationship was statistically weaker than the relationship between per capita income and personal bankruptcy filings. However, the overall finding that personal bankruptcies increase with income at a decreasing rate within counties located in Eighth District states is supportive of earlier research that suggests that individuals with lower-middle incomes are more likely to file for bankruptcy than individuals of other income groups.

Financial education is likely the key to reversing the decreasing social stigma associated with bankruptcy and thus reducing the demand for personal bankruptcies. Community groups and educators are best to decide how this is achieved. Even a strong public mission of financial education will not eliminate all bankruptcies, however, and that is why bankruptcy laws still need to be in place. Some individuals will have no choice but to file for bankruptcy despite responsible financial management.

\section{REFERENCES}

Barro, Robert and Sala-i-Martin, Xavier. Economic Growth. New York: McGraw Hill, 1995.

Barron, John M.; Staten, Michael E. and Wilshusen, Stephanie M. "The Impact of Casino Gambling on Personal Bankruptcy Filing Rates.” Contemporary Economic Policy, October 2002, 20(4), pp. 440-55.

Buckley, F.H. and Brinig, Margaret F. “The Bankruptcy Puzzle.” Journal of Legal Studies, January 1998, 27(1), pp. 187-207.
Carlino, Gerald and Mills, Leonard. "Convergence and the U.S. States: A Time Series Analysis." Journal of Regional Science, November 1996, 36(4), pp. 597-616.

de la Viña, Lynda and Bernstein, David. "The Impact of Gambling on Personal Bankruptcy Rates.” Journal of Socio-Economics, 2002, 31(5), pp. 503-09.

Domowitz, Ian and Eovaldi, Thomas L. "The Impact of the Bankruptcy Reform Act of 1978 on Consumer Bankruptcy." Journal of Law and Economics, October 1993, 36(2), pp. 803-35.

Durkin, Thomas. "Credit Cards: Use and Consumer Attitudes, 1970-2000.” Federal Reserve Bulletin, September 2000, 86(9), pp. 623-24.

Durlauf, Steven N. "Manifesto for a Growth Econometrics.” Journal of Econometrics, January 2001, 100(1), pp. 65-69.

Edmiston, Kelly D. “A New Perspective on Rising Nonbusiness Bankruptcy Filings Rates: Analyzing the Regional Factors." Federal Reserve Bank of Kansas City Economic Review, Second Quarter 2006, pp. 55-83.

Ellis, Diane. “The Effect of Consumer Interest Rate Deregulation on Credit Card Volumes, Charge-offs, and the Personal Bankruptcy Rate.” FDIC: Bank Trends, March 1998, Number 98-05.

Fan, Wei and White, Michelle J. "Personal Bankruptcy and the Level of Entrepreneurial Activity." Journal of Law and Economics, October 2003, 46(2), pp. 543-67.

Filer, Larry H. II and Fisher, Jonathan D. "The Consumption Effects Associated with Filing for Personal Bankruptcy." Southern Economic Journal, April 2005, 71(4), pp. 837-54.

Fisher, Jonathan D. "Marital Status and the Decision to file for Personal Bankruptcy: A Duration Model Approach." Journal of Economics and Finance, Fall 2004, 28(3), pp. 348-60.

Fisher, Jonathan D. "The Effect of Unemployment Benefits, Welfare Benefits, and Other Income on 
Personal Bankruptcy." Contemporary Economic Policy, October 2005, 23(4), pp. 483-92.

Gramlich, Edward M. "A Policy in Lampman's Tradition: The Community Reinvestment Act." Remarks at the Second Annual Robert J. Lampman Memorial Lecture, University of Wisconsin, Madison, June 16, 1999.

Gropp, Reint; Scholz, John Karl and White, Michelle J. "Personal Bankruptcy and Credit Supply and Demand." Quarterly Journal of Economics, February 1997, 112(1), pp. 217-51.

Hansen, Bradley and Hansen, Mary. "The Transformation of Bankruptcy in the United States." Working paper, University of Mary Washington, 2006.

Nelson, Jon P. "Consumer Bankruptcy and Chapter Choice: State Panel Evidence.” Contemporary Economic Policy, October 1999, 17(4), pp. 552-66.

Quah, Danny. "Empirical Cross-Section Dynamics in Economic Growth." European Economic Review, April 1993, 37(2/3), pp. 426-34.

Shepard, Lawrence. "Personal Failures and the Bankruptcy Reform Act of 1978." Journal of Law and Economics, October 1984a, 27(2), pp. 419-37.

Shepard, Lawrence. "Accounting for the Rise in Consumer Bankruptcy Rates in the United States: A Preliminary Analysis of Aggregate Data (19451981). Journal of Consumer Affairs, Winter 1984b, 18(2), pp. 213-30.
Sienkiewicz, Stan. "Credit Cards and Payment Efficiency." Payment Card Center Discussion Paper 01-02, Federal Reserve Bank of Philadelphia, August 2001.

Skeel, David A, Jr. Debt's Dominion: A History of Bankruptcy Law in America. Princeton, NJ: Princeton University Press, 2001.

Survey of Consumer Finances, 2004. Board of Governors of the Federal Reserve System; www.federalreserve.gov/PUBS/oss/oss2/2004/ scf2004home.html.

Thalheimer, Richard and Ali, Mukhtar M. "The Relationship of Pari-mutuel Wagering and Casino Gaming to Personal Bankruptcy." Contemporary Economic Policy, July 2004, 22(3), pp. 420-32.

U.S. Treasury Department. "A Study of the Interaction of Gambling and Bankruptcy." Washington, DC: GPO, 1999.

Visa USA, Inc. "Consumer Bankruptcy: Causes and Implications.” Visa Consumer Bankruptcy Reports, July 1996.

Webber, Don J; White, Paul and Allen, David O. "Income Convergence across U.S. States: An Analysis Using Measures of Concordance and Discordance." Journal of Regional Science, August 2005, 45(3), pp. 565-89. 
